\title{
Library in Hand and The Social Review as Adaptive Representation of Library Development Idea
}

\author{
Ifonilla Yenianti \\ Institut Agama Islam Negeri (IAIN) Salatiga, Jawa Tengah, Indonesia \\ ifon_2006@yahoo.com
}

\begin{abstract}
The development of technology and information brings a number of indispensable consequences, and it requires a wiser adaptation to apply them in the library to avoid the entailed negative impacts. This article discusses the idea of applying information technology of library in hand for library services. It is based on observations of the benchmarking activities in several countries and review on various literatures. Presentation and analysis are conducted descriptively, with the conclusion that the library should be about to adaptively follow the development of IT by considering the contextual social effects. In this context, the application of library in hand includes SMS gateway, Interactive Learning, Independent Learning, Online Reservation, and Online Library Information Retrieval. Meanwhile, the social effects that arise from this application are seen from three dimensions namely the structural, cultural and interactional ones. The result of this cases are every institution possible develop their library sevices by social media or application in the phone cell.
\end{abstract}

Keywords: Library in Hand, SMS Gateway, Interactive Learning, Independent Learning, Online Reservation, Social Effects. 


\section{Abstrak}

Perkembangan teknologi dan informasi membawa sejumlah konsekuensi yang tidak bisa ditawar tetapi memerlukan adaptasi yang lebih bijaksana untuk menerapkannya di perpustakaan untuk menghindari dampak negatif yang menyertainya. Artikel ini membahas tentang ide menerapkan teknologi informasi tentang library in hand untuk pelayanan perpustakaan. Penulisan ini didasarkan pada pengamatan dari kegiatan benchmarking dari beberapa negara dan pembacaan dari beberapa literatur penunjang. Metode penulisan ini menggunakan kualitatif research sederhana, dengan pendekatan fenomenologi dan survei. Penyajian dan analisis dilakukan secara deskriptif, dengan kesimpulan bahwa perpustakaan sudah saatnya secara adaptif mengikuti perkembangan TI dengan mempertimbangkan efek sosial. SMS gateway, Interactive Learning, Independent learning, Online Reservation, dan Online Library Information Retrieval. Efek sosial yang muncul dari penerapan ini dilihat dari tiga dimensi yaitu dimensi struktural, kultural dan interaksional.

Kata Kunci: Perpustakaan dalam Genggaman, SMS Gateway, Belajar Mandiri, Efek Sosial.

\section{A. Introduction}

Once upon a time, when electricity had not yet entered the village and the television was not possessed by the majority of the population, the villagers who wanted to watch a television program had to gather in the village chief (since the chief is the only person who has the television. Then not until the television program was watched fully, suddenly the storage battery energy (ACCU) which had been already used the whole day was critically running out of power, and finally the program could not be watched anymore.

Reaching a certain point of thinking, there was an idea that was "impossible" (in my mind) at that time; "it would be nice to watch a television by only watching it in hand, did not have to gather in a place, only opened the bag or grabbed in the pocket, pressed the power, searched for a 
particular channel and got ready to see the intended show. Then, it did not bother anymore by charging ACCU which was only lasted a few hours. It was really something very "difficult" to create this kind of thinking into a reality.

That is human from the view of philosophy in terms of having thinking realm and simultaneously developing from their experience and knowledge. Even the religious people also have the idea that human beings will think forward. However, no matter how advance and unique of human thoughts, they will not exceed the essence of humanity. It means that every human thought can be actualized because there is a synergy between human capacity and their ideas. ${ }^{1}$

The spirit seems to be applied to people who want to think, strive for innovation and actualize the ideas. For example, with relentless spirit and industrious work ethic, finally Japanese people are able to actualize their ideas, so they have assembled products that simplify the process of fulfilling human needs. Then how library perceives this interesting phenomenon.

\section{B. Discussion}

\section{The Role of Library}

Based on Undang-Undang No 43 Year 2007 defines a library as an institution that manages the collection of literature, printed work, and / or recorded work professionally based on a standard system to meet the needs of education, research, information preservation and recreation of the library users. However, formerly (in 1970s) American Library Association (ALA) ever has occupied the term of library for a broad sense, namely; media centers, learning centers, educational resource centers, information centers, documentation centers and referral centers. In such conventional environment, the role of library has already been discussed, and it come to a conclusion that the role for a library is status, position and organized place, whether the library is important, strategic, significant, influential, or only as

Pustaka Nun, 2016), 97. 
a complement and etc. ${ }^{2}$

It should bear in mind that in general the roles of library have not fulfilled the expectation. The role of the library is closely related to the expected performance because by having good performance, it will automatically improve the image of library. Communities will appreciate based on what benefits they have received.

From a broader perspective, the role of library is as an agent of change, development, culture, and advancement of science and technology. Changes always happen from time to time based on the current context in line with human nature of curiosity, exploratory, and culture base. In this case, the change includes the transformation of values, enrichment, and enlightenment of human life in order to maintain the balance of physical and spiritual life. Thus, human will not be trapped in material world and avoid the destruction from irresponsible people.

Once, a Descartes had used the term of Cogito ergo sum. It means "I think, therefore I exist". ${ }^{3}$ With such analogy, library is tangible, running, exist, and remain consistent to keep developing the vision, mission, performance, achievements and the image that should be recognized/utilized by people. It will be actual when it can compete with its skills.

\section{The Nature of Library in The Development Era}

The nature of library is as one tool of social and cultural interaction in a broader sense. Library is a meeting point of community at joint activities to develop science, technology and culture. The purpose of library is as a medium to educate national life and support national development. The progressive advancement of Information technology will greatly affect the development of library. Definitely, it will also change the meaning of library. Thus, the International Federation of Library Association and Institutions defines library as a set collection of printed materials, non-printed media, and sources of information in a computer that is systematically arranged for users.

2 Wiji Suwarno, Organisasi Informasi Perpustakaan:Pendekatan Teori Dan Praktik (Depok: Raja Grafindo Persada, 2016).

${ }^{3}$ Sulistyo-Basuki, Pengantar Ilmu Perpustakaan (Jakarta: Gramedia, 1991), 17. 
To actualize the development of economy in facing global competition, all elements should involve proactively and anticipatively. The Library Law, Article 1 No. 43 Year2007 states that "Library is an institution which professionally manages the collection of literature, printed work, and / or recorded work based on a standard system to meet the needs of education, research, conservation, information, and recreation of the library users."

The library manages all of the knowledge to disseminated to users so have no feel using the library is a scary, especially when We think about indepth research. We know that research cannot be done without frequent visits to the library. ${ }^{4}$ So that the library need developed continously.

The development of this era is marked by the very rapid changes in all areas of societal life. Library as an institution that orients to serves its users, must be sensitive with that change if it does not want to be neglected. Library must adapt quickly toward the current development, rather than isolate in its own world. Library does not need to change its on-going main function, but it must be actual in the current era. For that purpose, library must work hard to improve efficiency in running the function as an information organizer. ${ }^{5}$

Each library is responsible with the demands of management professionalism in order to answer the era development, respond and try to meet the needs of progressive users. The concept is not simple and endless, but it will simultaneously change, innovate and adapt to the environment of people's lives. In develop countries, library is a reflection of their civilized society, because library is a part of the basic needs. While in developing countries, the existence and attention of public to library is still very limited. The causes are diverse such as people are more or still concerned with the fulfillment of socio-economic needs before making library as the priority ones. Some people still want rather than need library. It means that people awareness and understanding of the importance of library services as a source of information and science have already existed, emerged and develop, but it does not become the top priority. Moreover, providing a

4 Constance A. Mellon, "Library Anxiety: A Grounded Theory and Its Development," College \& Research Libraries 47, no. 2 (1986): 163.

${ }^{5}$ Mellon, 12 . 
representative, well-distributed library and covering all levels of society still confront complex challenges.

There are several factors that cause library has not been able to develop well and independent such as (1) library organizers, (2) information sources and, (3) the user community. ${ }^{6}$ Library has not been able to provide the updated resources which needed by users, serve the community of users more professionally and compete with other service-based information institutions such as research centers, demographic institutions and business data centers.

Library organizers should be able to posit their positions appropriately, and then respond to the demands of the needs of organizational status, human, information, physical, and budgetary resources as well as promotions and publications. If they meet the expectation, then part of the problems has been resolved. The second factor is the ability to choose, collect / create and present information to users, and it significantly depends on the ability to choose, sort, compile / create and present what community needs. The third issue is developing a positive image and how to build perceptions, responses, and interests, and users' motivation. Harland said that users as a focus and orieantation of the library is a excelent services.

In a fast-pace world, every organization which manages information including library must be steady at least to survive or exist. Library is required to continue to cultivate its ability to have the power and strength in carrying out all activities. On the other hand, libraries cannot avoid tight and complex competitions. As a sample strategy, library can take advantages from the use of technology especially information and telecommunications technology. It offers a vast, simple, and efficient network.

The strategic method to develop human resources is through education and training, joining the meeting of scientific papers, conducting comparative studies, benchmarking to various developed libraries and cooperating with information and documentation center. This has been done by the Ministry of Religious Affairs through the manpower sub-directorate with Development Library and System Management (DELSMA) programs

\footnotetext{
${ }^{6}$ Sutarno NS, Manajemen Perpustakaan (Jakarta: Sagung Seto, 2006), 13.
} 
for several times. Benchmarking is intended to equip librarians to have ideas and apply them in their respective libraries.

It is something in need that library should conduct organizational learning to meet expectation. A library needs to stick to its main tasks and functions as an information agency, so it is required to be able to initiate change.

The availability of various sources of information and the savvy of information communication technology allows users to directly access information without library assistance. The library provides access to collections aligned with areas of research, curricular foci, or institutional strengths. Another task, the library provides collections that incorporate resources in a variety of formats, accessible virtually and physically. The library builds and ensures access to unique materials, including digital collections. The library has the infrastructure to collect, organize, provide access to, disseminate, and preserve collections needed by users. ${ }^{7}$ Thus, it arises assumption of what library can do farther? To answer that question, the library task can be seen as follows:

Identifying the presence of information.

A book may be published or promoted in a web. If no one knows its existence excluding the author, then the book does not inform anything for people. Thus, various information producers make a strategy, so that their work are recognized publicly as an effort to familiarize their existence into public knowledge. Various ways of publication may include publication, email promotion, reviews, making a list of related subjects, etc. Even some publishers create lists of catalogs and provide abstracts. In the context of library, the first task of institutions that conduct information organization activities is to track the existence of this information either in the form of printing such as books, journals, magazines and others, or that of non-printing like e-book, e-journal and many more. After the storage is found, the information is collected. As part of promotional strategies, publishers allow information seekers

${ }^{7}$ Budi Handarini, "Kontribusi Perpustakaan Terhadap Upaya Peningkatan Kualitas Perguruan Tinggi,” LIBRARIA: Jurnal Perpustakaan 4, no. 1 (2016): 147. 
to send email requesting any available and published information. Thus, the identification function of the existence of this information is highlighted on the search of information location .

Identifying information inside publications.

The next information organization activity is the effort to determine the information inside publications because that information is an important part of work. For example, a magazine contains articles, or a proceeding is compiled based on conference papers. essays is constructed from composition. they are the samples of information in published work.

More detailed identification activities are analyzing what information is contained in a publication. For example, we determine the subject of the publication, find the author, conclude the edition and so on. In line with that, it will be required when librarians or library organizers determine the subject, notation and bibliographic description that will be included in the catalog. As a matter of fact, the catalog is the roster or description of the physical characteristics of a book.

Collecting and collating information systematically

The activity of creating information is a traditionally hereditary activity in libraries, archives and museums. However, we should bear in mind that information will always appear and exist in different situations. For example, personal collections are arranged in such a way as the predicted need will look up available information in different time and places. In the context of library, the collected information was arranged and managed systematically, so users will be easy to find in the next visit. Shortly, the information in library is in the form of books, so they are compiled on a bookcase in a certain way based on the order of classification notation.

Making lists of documents and publications according to standard rules.

Publications or reference materials that are managed by library are not randomly arranged. The new library materials are not directly ordered on a bookshelf without passing circulation process. The incoming library materials firstly get through indexing process; creating a flow process to easily trace the work.. This indexing 
process will produce a row of documents on the bookshelf; neatly arranged work on the shelf, and the second result of this indexing process is the representative documents in the form of catalogs, indexes, bibliography, and others. For details of this process, it will be explained in the next modules.

Completing the lists with other useful access points.

Information that has been well captured, processed and managed is intended for easy access for users / library visitors. For that purpose, we need a tool to access that information by using a more specific access point, such as author, title and subject catalogs, or even the attached catalog. The access tool may not be through catalog. It can be through index, abstract or bibliography.

Providing tools to find out documents' location in the collection of information management agencies, and obtain the documents.

The following organizational activities are providing tools that can indicate the location of the information. At present, the information retrieval tools are not in the form of a conventional search tool such as a catalog card, catalog file, catalog sheets, and other printed search tools, but it has started to occupy computer based tools which is recognized as OPAC. ${ }^{8}$

Library also plays a role in providing access to electronic resources for those who do not have physical access, including the reproduction. Another role of library is to guide users to find and have a source of information that suits their needs based on the professionalism capabilities of library staff. The basic assumption is that not all information seekers are information users, and not all users can meet their own information needs especially when the subject is out of their expertise. In addition, library generally and traditionally plays roles of collecting, cataloging, and indexing library materials. The organizing skills of this information will make it easy to access both printed and electronic versions. ${ }^{9}$

8 Bunga Cintya Dewi and Desriyeni Desriyeni, "Pemanfaatan Perpustakaan Kantor Arsip, Perpustakaan, Dan Dokumentasi Kota Padang Bagi Masyarakat,” Ilmu Informasi Perpustakaan Dan Kearsipan 4, no. 1 (2015): 186. 24-26.

${ }^{9}$ Suwarno, Organisasi Informasi Perpustakaan:Pendekatan Teori Dan Praktik, 


\section{Library in Hand}

This article wrote based on qualitative reseach by suvey to the location in Austaria and India Libraries, and we used phenomenology approach. We can say that the library in hand seems to be possible based on todays' phenomena. For example, television is supposed to be a large tube, heavy, and require large space, but todays' fact refutes because everyone can watch television broadcast by opening a small device, pocket size, portable, and mobile. Everyone can easily access the broadcast of various television channels while sit back and relax, or even occasionally someone multitasks receiving a telephone call or receiving and sending messages (SMS) through the same device. The key word is the development of technology and information.

The development of technology and information affect the creativity of human activities in general. For example, making easy communication and accessing information is no longer laborious due to supportive facilities, adaptive computer equipment, abundant information. The impact is the emergence of single click and instant needs.

Sitting in front of a computer installed with the internet, someone can do a single click or more "clicks" to get the required information. By reflecting to current the phenomenon, air plane ticket reservations do not need to visit airports or booking agents. People have started to book a ticket from home, and the payment is by moving their finger tips on the phone buttons or visiting the nearest ATM machine. People have reached the effectiveness of time without hours ride to reach an agent or airport for a ticket. They do not need to stay in long lines to pay for tickets which have been already booked. That is what an acceleration of activity is. The remaining time can be used for other useful things. The IT development, certainly, should not make people unattended. The ease should not be discrete into bad images of a number of employees who are considered to have negative attitude such as: lazy while working, slow in providing services, corrupt and expect service rewards, nepotism in careers, anticriticism, and making a gap with colleagues. ${ }^{10}$

${ }^{10}$ Wiji Suwarno, "Diskursus Budaya Organisasi Kepustakawanan," LIBRARIA 3, no. 1 (2015): 4, http://journal.fppti.or.id/index.php/lib/article/view/23/27. 


\section{Between Social Progress and Impact}

Yesterday is a history, and the present time will be inseparable with previous milestones. The past time becomes a positive memory of life history, the present one is as the implementation of previous virtue, and the future time is a better change from the present one. It seems that this piece of sentence needs to be preserved as a wise spirit in response to various ongoing developments.

Currently, library find its time to follow those development. When the writer conducted benchmarking to Australia, there are some memories that are considered necessary to be shared in this article. The libraries in the University of Queensland and Queensland University of Technology are the inspiration to apply technology in the library with the various social impacts per se. There are some ideas of library development by utilizing today's emerging technologies with their social logical consequences.

a. SMS Gateway

The University of Queensland has implemented this service model. This idea can be applied by library in order to optimize services in the form of information via SMS, such as book reservations, overdue information, information of penalties, etc. As the consequence, the communication between library and users are getting more personal. When the users forget to return the books on time, the SMS will alarm as a reminder. The emotional connection between users and library will be indirectly created when the library attentively monitors users.

b. Interactive Learning

Another idea is the implementation of an interactive library system as community online learning media by either using computer, mobile phone or other devices connected to the Internet. We realize that library currently already has a number of collections of information in digital formats such as textbooks, magazines, journals or other digital collections. Users can use their devices to read e-books via e-book reader on the phone, and they can also access other information in the internet with various search engines installed in their phones, iPads or other devices. With their cell phones, users can provide comments or other suggestions to library 
without physically arrived into the library. It means that the users do not feel neglected with their anxiety due to halted communication between users with the library. With such technology, users can be more expressive convey their opinions. The users can ask or comment on reading materials they read, and the library can respond respectively. Interactive learning also connects distance users. It becomes a bridge between one user and another even though the distance cannot be reached within a short time.

c. Independent Learning

Technology of IPad, Tablets, Blackberries, Android and others have satisfied users to surf information in the virtual world. It is feasible to be applied in library as an independent learning media. Library plays as a database information provider. Meanwhile those devices work as transmitter medium between information in library with users. From a social perspective, the independent learning reduces interaction with other people. On the other hand, this activity helps user to improve time effectiveness and efficiency.

d. Online Reservation

The advancement of technology has an impact on the development of users' thinking process. Therefore, devices that are not regular for library services can be used as library services. One of the services is reservation of library materials. The reader does not have to search the information of collection in library. By using mobile device, users can visit library web. After that, they reserve books or other information in the library according to membership status. This method has relatively considered users' time in getting library services. Thus, the users can allocate more time other social activities.

e. Online Library Information Retrieval

Retrieving old information using representative documents of catalogs will be less usable. With the Online Public Access Catalog (OPAC), the searching is much more effective because it is simply typing a few keywords separately. Data can be viewed, and OPAC itself has already indicated the location of the collection only a few seconds. On the contrary, using a manual catalog will be difficult for those who have not complete searching keywords and take longer 
time. Now, the idea of searching using computers, netbooks or PC will shift to handy devices. Therefore, users do not have to go to the internet cafe to access the library online.

The most visible and inevitable consequence of the application of the five ideas above is the changing social dimension. In general, there are three dimensions namely structural, cultural, and interactional dimension. ${ }^{11}$ First, the structural dimension views on changing form the structure of society, changes of roles, the emergence of new roles, changes in the social class structure, and changes in social institutions.

Implementation of library in hand possibly change the structure of society in the position of economic level. When the library in hand has not been applied, the numbers of users may visit library with the feeling of togetherness to take advantages from the same library facilities and collections. After the library in hand is implemented, it is predicted that the quantity of visitors will reduce. The differences users' media in terms of types and brands will more or less impact to the perception of "able or not, rich or poor", which indirectly affect their interpersonal relationships.

Second, the cultural dimension from the perspective of the change of culture in society. The most tangible new culture is the emergence of new technology with various application models. The increasingly complex needs of society forces individuals to think creatively in order to meet those needs. The time before gadgets are becoming public can be very different from the times of gadget society. Previously, before gadgets became one of basic needs, intensive interaction among family members and the community still looks vivid. Once gadgets become "antique" and handy, communication between family members only transmitted through fingers on gadgets. People are silent from interaction and laughter. Likewise, the predictions of library in hand will reduce the interaction between the users respectively.

Third, interactional dimension perceives that there is a change in social relations in society when technology invade this area. One thing will appear as it has been already mentioned previously; the decline of individual

${ }^{11}$ Muhamad Ngafifi, "Kemajuan Teknologi Dan Pola Hidup Manusia Dalam Perspektif Sosial Budaya," Jurnal Pembangunan Pendidikan: Fondasi Dan Aplikasi 2, no. 1 (2014): 39, http://journal.uny.ac.id/index.php/jppfa/article/view/2616. 
frequency to meet each other. All issues for interaction can be satisfied by utilizing technology. A bank customer does not need to meet regularly with a bank teller. The function and role of the bank teller has been replaced by ATM (Automatic Teller Machine or Automated Teller Machine) that is capable to serve customers 24 hours regardless time and place, not having to long queue, or filling out a specific form. It means that in this context users do not have to meet librarians or library staff because their gadgets serve all transactions of library features. The transaction can be done from home, or users do not have to go to library especially if the required collection can be accessed online. In the aspect of the social gap, the development of information and communication technology has shifted the function of "face to face" in interaction process. A person does not have to meet face to face to communication and interact synchronously.

Another dimension that will appear is working mechanism. Individual working mechanisms in modern society are typically "online" in which the individual does not require assistance in the process of sending information.

\section{Conclusion}

We can summarize that library as an institution of growing organism must follow the development of technology and information by creating ideas as part of the adaptation of service to users. The ideas of library in hand application are SMS gateway, Interactive Learning, Independent Learning, Online Reservation, and Online Library Information Retrieval. Whereas, social perspectives related to technological development and application of the ideas of library in hand include the structural, cultural and interactional dimensions. The result of this cases are every institution possible develop their library sevices by social media or application in the phone cell. 


\section{DAFTAR PUSTAKA}

Dewi, Bunga Cintya, and Desriyeni Desriyeni. "Pemanfaatan Perpustakaan Kantor Arsip, Perpustakaan, Dan Dokumentasi Kota Padang Bagi Masyarakat." Ilmu Informasi Perpustakaan Dan Kearsipan 4, no. 1 (2015): 184-191.

Mellon, Constance A. "Library Anxiety: A Grounded Theory and Its Development." College \& Research Libraries 47, no. 2 (1986): 160165.

Ngafifi, Muhamad. "Kemajuan Teknologi Dan Pola Hidup Manusia Dalam Perspektif Sosial Budaya." Jurnal Pembangunan Pendidikan: Fondasi Dan Aplikasi 2, no. 1 (2014). http://journal.uny.ac.id/index.php/jppfa/article/view/2616.

Sulistyo-Basuki. Pengantar Ilmu Perpustakaan. Jakarta: Gramedia, 1991.

Sutarno NS. Manajemen Perpustakaan. Jakarta: Sagung Seto, 2006.

Suwarno, Wiji. "Diskursus Budaya Organisasi Kepustakawanan." LIBRARIA 3, no. 1 (2015). http://journal.fppti.or.id/index.php/lib/article/view/23/27.

- Library life style: Trend dan ide kepustakawanan. Yogyakarta: Pustaka Nun, 2016.

- Organisasi Informasi Perpustakaan:Pendekatan Teori Dan Praktik. Depok: Raja Grafindo Persada, 2016. 
